\title{
Assestment of hospital service quality from the view of physician, patient and health managers
}

\section{Hastane hizmet kalitesinin hekim, hasta ve sağlık yöneticisi bakış açısıyla değerlendirilmesi}

\author{
Nurperihan Tosun', Sümeyye Arslan Kurtuluşs²
}

' Department of Health Management, Health Science Faculty, Sivas Cumhuriyet University, Sivas, Turkey

2 Department of Health Management, Health Science Faculty,Istanbul Medeniyet University, Istanbul, Turkey

Corresponding author: Nurperihan Tosun, PhD, Department of Health Management, Health Science Faculty, Sivas Cumhuriyet University, Sivas, Turkey

E-mail: nurperihankarabulut@gmail.com

Received/Accepted: November 13,2019/May 20, 2020

Conflict of interest: There is not a conflict of interest.

\section{SUMMARY}

Objective: Today, increasing competition conditions, increasing costs, changing the diagnosis and treatment methods with the advancement of technology, and increasing patient expectations increase the importance of service quality in the health sector.

The aim of this study is to evaluate the service quality in hospital from the perspective of patients, hospital managers and physicians.

Method: The population and sample of the study consisted of physicians, patients and hospital managers in Sivas Numune Hospital. The study was conducted with 60 participants who voluntarily agreed to participate. Twopart survey method was used as data collection tool. In the first part, the questions about the identifier characteristics of the participants and the second part are the five-dimensional SERVPERF scale. The data were collected by the researcher between 25.04.2019 and 10.05.2019 by face to face interview technique. AHP analysis was performed in the study.

Findings and Results: The study was carried out with 20 patients, 20 physicians and 20 managers. $66.7 \%$ of the participants were male; $73.3 \%$ were married and $76 \%$ of them are at undergraduate and graduate level. $70 \%$ of the patients participated in the study provided 3 or more applications. According to the results of AHP analysis, reliability, responsiveness, assurance, tangibles and empathy dimension were found to be important for the evaluation of service quality. The importance of physicians for tangibles, empathy, assurance, reliability and responsiveness. For hospital managers, the importance rankings are empathy, tangibles, reliability, assurance and responsiveness. Although there are studies evaluating hospital service quality from the perspective of patients in the literature, there are no studies evaluating the internal and external stakeholders together.

Keywords: Service quality, analytic hierarchy process, hospital
Nurperihan Tosun

Sümeyye Aslan Kurtuluş

ORCID IDs of the authors:

N.T. 0000-0001-6548-3099

S.A.K. 0000-0003-4782-5061 
Bu çalıșmanın amacı hastanede hizmet kalitesinin boyutlarının önemlilik derecesinin hasta, hastane yöneticisi ve hekimlerin perspektifinden değerlendirilmesidir.

Yöntem: Çalışmanın evren ve örneklemini Sivas Numune Hastanesi hekim, hasta ve hastane yöneticileri oluşturmuştur. Çalışmaya katılmayı gönüllü olarak kabul eden 60 kişi ile gerçekleştirilmiştir. Veri toplama aracı olarak iki bölümden oluşan anket yöntemi kullanılmıştır. Birinci bölümde katılımcıların tanıtıcı özelliklerine yönelik sorular, ikinci bölümde ise beş boyutlu SERVPERF ölçeği yer almaktadır. Veriler, 25.04.2019-10.05.2019 tarihleri arasında araştırmacının kendisi tarafindan yüz yüze görüş̧me tekniği kullanılarak toplanmıştır. Çalışma Analitik Hiyerarşi Süreci (AHP) ile gerçekleştirilmiştir. AHP analizinde katılımcılar kriterler arasında ikili karşılaştırmalar yapmış ve en önemli kriterler ortaya çımıstır.

Bulgular ve Sonuç: Çalışma 20 hasta, 20 hekim ve 20 yönetici ile yürütülmüştür. Çalışmaya katılanların \%66,7'si erkek; \%73,3’ü evli; \%56.7'si 30-49 yaş aralığında, \%76'sının lisans ve lisansüstü seviyededir. Çalışmaya katılan hastaların \%70'i 3 ve üzerinde hastaneye başvuru sağlamıștır. AHP analizi sonuçlarına göre hizmet kalitesinin değerlendirilmesinde hastalar için sırasıyla güvenilirlik, heveslilik, güvence, fiziksel özellikler ve empati boyutu önemli bulunmuştur. Hekimler için önem sıralaması fiziksel özellikler, empati, güvence, güvenilirlik ve hevesliliktir. Hastane yöneticileri için ise önem sıralaması empati, fiziksel özellikler, güvenilirlik, güvence ve hevesliliktir.

Anahtar sözcükler: Hizmet kalitesi, analitik hiyerarşi süreci, hastane

*Bu makale 20-23 Haziran 2019 tarihlerinde İstanbul'da düzenlenen 4.Uluslararası Sağlık Bilimleri ve Yönetim Kongresinde sunulan sözel bildirinin genişletilmiş halidir.

\section{INTRODUCTION}

In today's highly competitive health care environment, all hospitals in public and private sectors are confronted with the necessity of measuring both their financial (costs, revenues, profitability) and non-financial performance (quality of their services), in order to improve their functions and increase their competitiveness (Chaniotakis and Lymperopoulos, 2009). Although health care services have distinctive characteristics by their nature, they also involve high risks. This situation makes it more important to conceptualize and measure customer satisfaction and service quality in health care services compared to the other sectors (Rashid and Jusoff, 2008).

Service quality was also considered as a strategic value in parallel to the improvements related to quality concept in the world and is continuing to be among the subjects interesting the researchers and managers due to its strong impacts on the concepts such as performance, low cost, profitability, customer satisfaction and loyalty (Seth et al., 2004; Biçer and Gülmez, 2016; Özgün Ova et al., 2019).

Although service quality has many definitions, the general framework of this concept is based on definition and satisfaction of customer requests and needs. Parasuram et al., (1985) suggest that service quality can be defined as the difference between the predicted or expected service (customer expectations) and the perceived service (customer perceptions). Bolton and Drew (1991) described service quality as a form of attitude related but not equivalent to satisfaction, that result from comparison of expectations with performance.
Service quality is essential to ensure patient satisfaction and also an important factor affecting the patient's intention to get the service again and loyalty. Therefore, quality has to be understood, measured and improved by the public and private health care institutions (Demirer and Bülbül, 2014).

\section{Service Quality Measurement Methods}

When the service quality literature is examined, it is seen that there are a series of studies performed by Parasuraman et al. related to definition, model, dimensions and measurement of service quality (Parasuraman et al., 1985; Parasuraman et al., 1988; Zeithaml et al., 1988; Zeithaml et al., 1996; Parasuraman et al. 1991). As a result of the studies, service quality was defined, a conceptual model was proposed and SERVQUAL measuring instrument was developed based on service quality model. They developed the Service Quality Scale (SERVQUAL) on 1988. SERVQUAL scale consists of five dimensions and 22 items. These five dimensions are tangibles, empathy, assurance, reliability and responsiveness. The mentioned five dimensions form a basis for other studies and can be adapted for different service institutions (Parasuraman et al., 1988).

It is important for the health care institutions to provide effective and quality service, understand perceptions of all stakeholders and plan end execute the services accordingly to achieve success. Accordingly, it was aimed in this study to determine the importance level of the service quality dimensions in the sample of physicians determining the consumption of health care service, patients using the service and hospital 
managers. Although there are studies aiming to determine service quality from the perspective of patient in the literature (Rahman et al., 2007; Gülmez and Kitapçı, 2008; Zaim and Tarım, 2010; $\mathrm{Hu}$ et al., 2010; Nekoei-Moghadam and Amiresmaili, 2011; Papatya et al. 2012; Al-Borie and Damanhouri, 2013; Savaş and Kesmez, 2014; Rezaei et al, 2016; Nadi et al., 2016; Pekkaya et al., 2017; Çağlıyan, 2017; Shafiq et al., 2017; Tripathi and Siddiqui, 2018; Qolipour et al., 2018) the studies determining service quality from the perspective of physician and managers are very limited (Singh, 2018). Since this study evaluates the hospital service quality from the perspective of physician, health care manager and patient in this respect, it is thought that it will make important contributions to the literature.

\section{MATERIAL AND METHODS}

\section{Universe and Sample}

The universe of the study consists of the specialist physicians and managers working at the Sivas Numune hospital and the patients applying to the hospital outpatient clinic. The sample of the study consists of 20 specialist physicians, 20 managers and 20 outpatient clinic patients who agreed to participate in the study. Therefore, the sample number was determined as 60 .

\section{Data Collection Tool}

Questionnaire was used for data collection. The questionnaire consists of two parts. The first part includes the socio-demographic information related to the participants. The second part includes the criteria related to the service quality and 1-9 scale Developed by Thomas L. Saaty was used. The factors related to the SERVQUAL service quality scale developed by Parasuraman et al., (1985) were determined as the service quality factors and Saaty 1-9 scale was used.

\section{Data Collection Process}

The questionnaires were applied to the participants face to face by the researchers. The study was based on voluntariness and the questionnaire was applied to 60 people consisting of patients, specialist physicians and managers who agreed to participate in the study and were able to evaluate the service quality of the hospital. The application was performed on April 25 - May 10, 2019.

\section{Data Analysis}

In this cross-sectional study, descriptive statistics were used for determination of demographic characteristics of the participants with the Analytical Hierarchy Process (AHP) analysis. The SPSS Statistics 23.0 package program was used for the descriptive statistics and Microsoft Excel program was used for AHP analysis. The factors related to the SERVQUAL service quality scale were determined as the service quality criteria for this study and weighted by comparison of the relatively determined criteria of the participants with AHP.

\section{Analytical Hierarchy Process (AHP) Analysis}

Analytical Hierarchy Process developed by Thomas L. Saaty for solution of the multi-criteria decision-making problems in the 1970s is a technique that requires expert opinions in determination of the criteria and the importance levels. The experts, i.e., the decision makers compare the criteria and the sub-criteria by filling in the questionnaires prepared by using the 1-9 scale of Saaty. In this method, the importance levels between the criteria can be determined relatively by the decision makers and the priority order of the decision alternatives can be obtained (Önder and Önder, 2013).

If there are more than one criterion for decision making and evaluation of the options and the impacts of these criteria on the decision to be made are not equal, it is possible to sort the options by making pairwise comparisons of the decision options with AHP. AHP determines the importance levels of the criteria and the sub-criteria and thus reduces a multi-dimensional problem to onedimensional one. The decisions can be calculated with the priority vectors that constitute sorting to obtain the best one among many possible results.

Different package programs such as "Expert Choice" and "Super Decision" can be used while using AHP technique in decision-making problems. There are visual tools and menus to create model in these programs. In addition, AHP model can also be easily modeled and solved in Ms. Excel (Önder and Önder, 2015). In this study, AHP analysis was used to determine which one of the sub-criteria of the SERVQUAL service quality factors has higher relative importance.

\section{Research Permit}

The necessary written permits were obtained from the Cumhuriyet University Non-Invasive Clinical Researches Ethics Committee for the research and from the Sivas Numune Hospital for data collection.

\section{RESULTS}

In this section, first of all the descriptive data of the sample will be mentioned and then the findings related to the AHP analysis including evaluation of 
the service quality criteria from the point of view of patient, physician and manager will be included.

\section{Descriptive Data of the Study Sample}

The study was performed with 20 patients, 20 specialist physicians and 20 managers. In the study, $66.7 \%$ of the participants are male; $73.3 \%$ of the participants are married and $56.7 \%$ of the participants are in the 30-49 age range. $17 \%$ of them are high school graduates; $7 \%$ of them have associate's degree and 76\% of them have bachelor's degree and master's degree. It is seen that $30 \%$ of the participant in the study applied hospital 1-2 times and $70 \%$ of them applied 3 or more times. $70 \%$ of the physicians participated in the study were working in internal branches and $30 \%$ of them were working in surgical branches (Table 1).

Table 1: Descriptive Characteristics of Participants $(\mathrm{N}=60)$

\begin{tabular}{|c|c|c|}
\hline & $\mathbf{N}$ & $\%$ \\
\hline \multicolumn{3}{|l|}{ Gender } \\
\hline \multirow{2}{*}{$\begin{array}{l}\text { Male } \\
\text { Famele }\end{array}$} & 40 & 66,7 \\
\hline & 20 & 33,3 \\
\hline \multicolumn{3}{|l|}{ Age } \\
\hline \multirow{4}{*}{$\begin{array}{l}20-29 \\
30-39\end{array}$} & 11 & 18,3 \\
\hline & 23 & 38,3 \\
\hline & 23 & 38,3 \\
\hline & 3 & 5,0 \\
\hline \multicolumn{3}{|l|}{ Education } \\
\hline \multirow{4}{*}{$\begin{array}{l}\text { High school } \\
\text { Associate degree } \\
\text { Undergraduate } \\
\text { Postgraduate }\end{array}$} & 10 & 16,7 \\
\hline & 4 & 6,7 \\
\hline & 19 & 31,7 \\
\hline & 27 & 45,0 \\
\hline \multicolumn{3}{|l|}{ Marital status } \\
\hline \multirow{2}{*}{$\begin{array}{l}\text { Married } \\
\text { Single }\end{array}$} & 44 & 73,3 \\
\hline & 16 & 26,7 \\
\hline \multicolumn{3}{|c|}{ Frequency of patients coming to hospital } \\
\hline \multirow{2}{*}{$\begin{array}{l}1-2 \text { times } \\
3 \text { times and more }\end{array}$} & 6 & 30,0 \\
\hline & 14 & 70,0 \\
\hline \multicolumn{3}{|c|}{ Physicians speciality } \\
\hline \multirow{3}{*}{$\begin{array}{l}\text { Internal Medicine } \\
\text { Surgery Medicine } \\
\text { TOTAL }\end{array}$} & 14 & 70,0 \\
\hline & 6 & 30,0 \\
\hline & 20 & 100,0 \\
\hline
\end{tabular}

In the AHP process stage, pairwise comparison matrices are obtained by calculating the geometric mean of the pairwise comparisons made by patients, physicians and managers. Then, the vector of priorities can be calculated by performing normalization on this matrix. The matrix of all priorities is obtained in the following stages and after dividing this matrix by the means, the maximum value is calculated by calculating the means again. In order to calculate fit index, the number of criteria is subtracted from the maximum value and then this result is divided by fit number- 
minus one. Consistency ratio is calculated by dividing the fit index by random index included in the literature. Fit index less than 0.10 indicates that the sorting obtained from the vector of priorities can be used (Önder and Önder, 2015). The pairwise comparison matrix obtained from the geometric mean of the pairwise comparisons of the patients, physicians and managers and the vector of priorities obtained as a result of the calculations are given in Table 2, Table 3 and Table 4. Then, the pairwise comparison matrices are normalized and the vector of priorities was obtained. Then, the matrix of all priorities is obtained. The fit index indicating that the pairwise comparisons can be used was calculated from these calculations by using the maximum value, the fit index and the random index by means of Excel. The value obtained according to the fit index calculation was determined as 0.002 for the physicians, 0.006 for the patients and 0.003 for the managers respectively, and since the values obtained in all groups are less than 0.10 , it was concluded that the comparisons are consistent and can be used.

According to Table 2, the most important dimension among the service quality dimensions from the point of view of the physicians is tangibles and it is followed by empathy, assurance and reliability and finally responsiveness respectively. According to Table 3, the most important dimension among the service quality dimensions from the point of view of the patients is reliability and it is followed by responsiveness, assurance and tangibles and empathy respectively. According to Table 4, the most important dimension among the service quality dimensions from the point of view of the managers is empathy and it is followed by reliability, tangibles, assurance and responsiveness respectively.

Table 2: Comparison of Main Service Quality Criteria (Physicians)

\begin{tabular}{|c|c|c|c|c|c|c|}
\hline Criteria & $\mathbf{T}$ & $\mathbf{R}$ & $\mathbf{R S}$ & $\mathbf{A}$ & $\mathbf{E}$ & PRIORITY VECTOR \\
\hline $\mathbf{T}$ & 1,00 & 1,48 & 1,80 & 1,50 & 0,90 & 0,33 \\
\hline $\mathbf{R}$ & 0,67 & 1,00 & 1,25 & 1,02 & 0,80 & 0,23 \\
\hline $\mathbf{R S}$ & 0,55 & 0,80 & 1,00 & 0,81 & 0,78 & 0,19 \\
\hline $\mathbf{A}$ & 0,66 & 0,98 & 1,23 & 1,00 & 0,88 & 0,23 \\
\hline $\mathbf{E}$ & 1,11 & 1,25 & 1,28 & 1,13 & 1,00 & 0,28 \\
\hline TOTAL & 3,99 & 5,51 & 6,56 & 5,46 & 4,36 & \\
\hline \multicolumn{6}{|l|}{$\mathrm{CR}=0,002$} & \\
\hline
\end{tabular}

Table 3: Comparison of Main Service Quality Criteria (Patients)

\begin{tabular}{|c|c|c|c|c|c|c|}
\hline Criteria & $\mathbf{T}$ & $\mathbf{R}$ & $\mathbf{R S}$ & A & $\mathbf{E}$ & \multirow{2}{*}{$\begin{array}{l}\text { PRIORITY VECTOR } \\
0,15\end{array}$} \\
\hline $\mathbf{T}$ & 1,00 & 0,68 & 0,67 & 0,89 & 1,25 & \\
\hline $\mathbf{R}$ & 1,48 & 1,00 & 1,14 & 1,02 & 1,14 & \multirow{5}{*}{0,15} \\
\hline $\mathbf{R S}$ & 1,49 & 0,88 & 1,00 & 1,05 & 1,10 & \\
\hline $\bar{A}$ & 1,12 & 0,98 & 0,95 & 1,00 & 1,31 & \\
\hline $\mathbf{E}$ & 0,8 & 0,88 & 0,90 & 0,76 & 1,00 & \\
\hline TOTAL & 5,89 & 4,42 & 4,66 & 4,72 & 5,80 & \\
\hline \multicolumn{6}{|l|}{$\mathrm{CR}=0,006$} & \\
\hline
\end{tabular}


Table 4: Comparison of Main Service Quality Criteria (Managers)

\begin{tabular}{|c|c|c|c|c|c|c|}
\hline Criteria & $\mathbf{T}$ & $\mathbf{R}$ & $\mathbf{R S}$ & $\mathbf{A}$ & $\mathbf{E}$ & PRIORITY VECTOR \\
\hline $\mathbf{T}$ & 1,00 & 1,00 & 1,54 & 0,99 & 0,90 & 0,22 \\
\hline $\mathbf{R}$ & 1,00 & 1,00 & 1,18 & 1,18 & 1,01 & 0,22 \\
\hline $\mathbf{R S}$ & 0,65 & 0,85 & 1,00 & 1,07 & 0,81 & 0,18 \\
\hline $\bar{A}$ & 1,01 & 0,85 & 0,93 & 1,00 & 0,82 & 0,19 \\
\hline $\mathbf{E}$ & 1,10 & 0,99 & 1,23 & 1,21 & 1,00 & 0,23 \\
\hline TOTAL & 4,76 & 4,69 & 5,88 & 5,45 & 4,54 & \\
\hline
\end{tabular}

Determination of the importance levels by weighting the criteria as a result of the pairwise comparisons made for tangibles, reliability, responsiveness, assurance and empathy from the point of view of the patients, physicians and managers are included in this section of the study. Accordingly, the results are given in Tables 5, 6 and 7.

Table 5: Comparison of Tangibles Criteria

\begin{tabular}{|c|c|c|c|c|c|}
\hline \multicolumn{6}{|l|}{ Patient } \\
\hline Criteria & T1 & $\mathbf{T 2}$ & T3 & $\mathbf{T 4}$ & \multirow{7}{*}{$\begin{array}{l}\text { PRIORITY VECTOR } \\
0,22 \\
0,21 \\
0,28 \\
0,27\end{array}$} \\
\hline T1 & 1,00 & 0,94 & 0,78 & 0,78 & \\
\hline T2 & 1,06 & 1,00 & 0,71 & 0,72 & \\
\hline T3 & 1,28 & 1,41 & 1,00 & 0,84 & \\
\hline T4 & 1,28 & 1,38 & 0,72 & 1,00 & \\
\hline TOTAL & 4,62 & 4,73 & 3,20 & 3,33 & \\
\hline \multicolumn{5}{|c|}{$\mathrm{CR}=-0,04$} & \\
\hline \multicolumn{5}{|c|}{ Physician } & \multirow{7}{*}{$\begin{array}{l}\text { PRIORITY VECTOR } \\
0,25 \\
0,28 \\
0,24 \\
0,21\end{array}$} \\
\hline Criteria & T1 & $\mathbf{T 2}$ & T3 & T4 & \\
\hline T1 & 1,00 & 0,88 & 0,92 & 1,30 & \\
\hline $\mathbf{T 2}$ & 1,13 & 1,00 & 1,04 & 1,34 & \\
\hline T3 & 0,96 & 0,92 & 1,00 & 1,08 & \\
\hline T4 & 0,76 & 0,74 & 0,92 & 1,00 & \\
\hline \multicolumn{5}{|c|}{$\mathrm{CR}=-0,016$} & \\
\hline \multicolumn{6}{|c|}{ Managers } \\
\hline Criteria & T1 & $\mathbf{T 2}$ & T3 & $\mathbf{T 4}$ & \multirow{6}{*}{$\begin{array}{l}\text { PRIORITY VECTOR } \\
0,26 \\
0,29 \\
0,20 \\
0,23\end{array}$} \\
\hline T1 & 1,00 & 0,82 & 1,36 & 1,23 & \\
\hline $\mathbf{T 2}$ & 1,21 & 1,00 & 1,37 & 1,23 & \\
\hline T3 & 0,73 & 0,72 & 1,00 & 0,85 & \\
\hline $\mathbf{T 4}$ & 0,81 & 0,81 & 1,17 & 1,00 & \\
\hline TOTAL & 3,75 & 3,35 & 4,90 & 4,31 & \\
\hline
\end{tabular}


The tangibles criteria of the hospital were compared from the point of view of the patients, physicians and managers and the results are shown in Table 5. Accordingly, while the most important dimension of the tangibles of the hospital from the point of view of the patients is the well-groomed and natty employees (T3), it is visually attractive physical environment from the point of view of the physicians (T2). Finally, the most important dimension of the tangibles of the hospital from the point of view of the managers is visually attractive physical environment.

Table 6: Comparison of Reliability Criteria

\begin{tabular}{|c|c|c|c|c|c|c|}
\hline \multicolumn{7}{|l|}{ Patient } \\
\hline Criteria & R1 & $\mathbf{R 2}$ & $\mathbf{R 3}$ & R4 & R5 & \multirow{2}{*}{$\begin{array}{l}\text { PRIORITY VECTOR } \\
0,18\end{array}$} \\
\hline $\mathbf{R} 1$ & 1,00 & 1,06 & 0,84 & 0,86 & 0,81 & \\
\hline $\mathbf{R 2}$ & 0,94 & 1,00 & 0,78 & 0,81 & 0,69 & \multirow{6}{*}{$\begin{array}{l}0,16 \\
0,21 \\
0,19 \\
0,23\end{array}$} \\
\hline $\mathbf{R 3}$ & 1,19 & 1,28 & 1,00 & 1,15 & 0,91 & \\
\hline $\mathbf{R 4}$ & 1,16 & 1,23 & 0,86 & 1,00 & 0,81 & \\
\hline R5 & 1,23 & 1,45 & 1,10 & 1,23 & 1,00 & \\
\hline TOTAL & 5,52 & 6,02 & 4,58 & 5,05 & 4,22 & \\
\hline \multicolumn{6}{|c|}{$\mathrm{CR}=-0,0006$} & \\
\hline \multicolumn{6}{|c|}{ Physician } & \multirow{8}{*}{$\begin{array}{l}\text { PRIORITY VECTOR } \\
0,15 \\
0,25 \\
0,23 \\
0,14 \\
0,21\end{array}$} \\
\hline R1 & 1,00 & 0,69 & 0,65 & 1,04 & 0,63 & \\
\hline $\mathbf{R 2}$ & 1,44 & 1,00 & 1,32 & 1,64 & 1,13 & \\
\hline $\mathbf{R 3}$ & 1,53 & 0,75 & 1,00 & 1,66 & 1,19 & \\
\hline $\mathbf{R 4}$ & 0,96 & 0,61 & 0,6 & 1,00 & 0,70 & \\
\hline $\mathbf{R 5}$ & 1,58 & 0,88 & 0,84 & 1,42 & 1,00 & \\
\hline TOTAL & 6,51 & 3,93 & 4,42 & 6,77 & 4,66 & \\
\hline \multicolumn{6}{|l|}{$\mathrm{CR}=0,004$} & \\
\hline \multicolumn{6}{|l|}{ Managers } & \multirow{8}{*}{$\begin{array}{l}\text { PRIORITY VECTOR } \\
0,20 \\
0,19 \\
0,18 \\
0,21 \\
0,20\end{array}$} \\
\hline R1 & 1,00 & 1,04 & 1,11 & 1,00 & 0,90 & \\
\hline $\mathbf{R 2}$ & 0,96 & 1,00 & 0,94 & 0,92 & 0,96 & \\
\hline $\mathbf{R 3}$ & 0,90 & 1,06 & 1,00 & 0,92 & 0,87 & \\
\hline $\mathbf{R 4}$ & 1,00 & 1,08 & 1,08 & 1,00 & 1,13 & \\
\hline R5 & 1,11 & 1,04 & 1,14 & 0,88 & 1,00 & \\
\hline TOTAL & 4,97 & 5,22 & 5,27 & 4,72 & 4,86 & \\
\hline \multicolumn{6}{|c|}{$\mathrm{CR}=-0,0002$} & \\
\hline
\end{tabular}

The reliability criteria of the hospital were compared from the point of view of the patients, physicians and managers and the results are shown in Table 6. Accordingly, while the most important dimension of the reliability of the hospital from the point of view of the patients is keeping of the records correctly by the hospital (R5), the most important dimension of the reliability from the point of view of the physicians is solution of the problems of the patients by the hospital, when patients encounter problems (R2). The most important criterion from the point of view of the managers is provision of all kinds of services by the hospital at the promised time (R4). Responsiveness 
Table7: Comparison of Responsiveness Criteria

\begin{tabular}{|c|c|c|c|c|c|}
\hline \multicolumn{6}{|l|}{ Patient } \\
\hline Criteria & RS1 & RS2 & RS3 & RS4 & \multirow{2}{*}{$\begin{array}{l}\text { PRIORITY VECTOR } \\
0,258\end{array}$} \\
\hline RS1 & 1,00 & 1,11 & 0,90 & 1,13 & \\
\hline RS2 & 0,90 & 1,00 & 0,96 & 0,90 & \multirow{5}{*}{$\begin{array}{l}0,234 \\
0,254 \\
0,253\end{array}$} \\
\hline $\mathrm{RS3}$ & 1,11 & 1,04 & 1,00 & 0,92 & \\
\hline RS4 & 0,88 & 1,11 & 1,08 & 1,00 & \\
\hline TOTAL & 3,89 & 4,26 & 3,94 & 3,95 & \\
\hline \multicolumn{5}{|c|}{$\mathrm{CR}=0,001$} & \\
\hline \multicolumn{5}{|c|}{ Physician } & \multirow{7}{*}{$\begin{array}{l}\text { PRIORITY VECTOR } \\
0,30 \\
0,29 \\
0,25 \\
0,14\end{array}$} \\
\hline RS1 & 1,00 & 1,17 & 1,09 & 1,94 & \\
\hline $\mathrm{RS} 2$ & 0,85 & 1,00 & 1,33 & 2,11 & \\
\hline RS3 & 0,91 & 0,75 & 1,00 & 1,76 & \\
\hline RS4 & 0,51 & 0,47 & 0,56 & 1,00 & \\
\hline TOTAL & 3,27 & 3,39 & 3,98 & 6,81 & \\
\hline \multicolumn{5}{|l|}{$\mathrm{CR}=-2,03$} & \\
\hline \multicolumn{5}{|l|}{ Managers } & \multirow{7}{*}{$\begin{array}{l}\text { PRIORITY VECTOR } \\
0,34 \\
0,24 \\
0,26 \\
0,15\end{array}$} \\
\hline Criteria & RS1 & RS2 & RS3 & RS4 & \\
\hline RS1 & 1,00 & 1,47 & 1,33 & 2,09 & \\
\hline $\mathrm{RS} 2$ & 0,68 & 1,00 & 0,97 & 1,63 & \\
\hline RS3 & 0,75 & 1,03 & 1,00 & 1,80 & \\
\hline $\mathrm{RS} 4$ & 0,47 & 0,61 & 0,55 & 1,00 & \\
\hline \multicolumn{5}{|c|}{$\mathrm{CR}=-0,002$} & \\
\hline
\end{tabular}

The responsiveness criteria of the hospital were compared from the point of view of the patients, physicians and managers and the results are shown in Table 7. Accordingly, the most important one of the responsiveness criteria from the point of view of the patients, physicians and managers is informing of the patients by the hospital about the time of the service to be provided (RS1).

Table 8: Comparison of Assurance Criteria

\begin{tabular}{|c|c|c|c|c|c|}
\hline \multicolumn{5}{|l|}{ Patient } & \multirow{2}{*}{$\begin{array}{l}\text { PRIORITY VECTOR } \\
0,24\end{array}$} \\
\hline Criteria & A1 & A2 & $\mathbf{A 3}$ & A4 & \\
\hline A1 & 1,00 & 1,08 & 0,88 & 0,96 & \multirow{6}{*}{$\begin{array}{l}0,23 \\
0,27 \\
0,25\end{array}$} \\
\hline A2 & 0,92 & 1,00 & 0,82 & 0,96 & \\
\hline A3 & 1,13 & 1,21 & 1,00 & 1,04 & \\
\hline A4 & 1,04 & 1,04 & 0,96 & 1,00 & \\
\hline TOTAL & 4,09 & 4,33 & 3,66 & 3,96 & \\
\hline \multicolumn{5}{|c|}{$\mathrm{CR}=-0,001$} & \\
\hline \multicolumn{5}{|c|}{ Physician } & \multirow{7}{*}{$\begin{array}{l}\text { PRIORITY VECTOR } \\
0,29 \\
0,25 \\
0,20 \\
0,25\end{array}$} \\
\hline A1 & 1,00 & 1,33 & 1,38 & 1,08 & \\
\hline $\mathbf{A 2}$ & 0,75 & 1,00 & 1,33 & 1,08 & \\
\hline $\mathbf{A 3}$ & 0,72 & 0,75 & 1,00 & 0,80 & \\
\hline A4 & 0,92 & 0,92 & 1,25 & 1,00 & \\
\hline TOTAL & 3,39 & 4,00 & 4,96 & 3,96 & \\
\hline \multicolumn{5}{|c|}{$\mathrm{CR}=0,001$} & \\
\hline \multicolumn{5}{|c|}{ Managers } & \multirow{7}{*}{$\begin{array}{l}\text { PRIORITY VECTOR } \\
0,24 \\
0,27 \\
0,20 \\
0,27\end{array}$} \\
\hline A1 & 1,00 & 0,93 & 1,10 & 0,96 & \\
\hline A2 & 1,07 & 1,00 & 1,38 & 1,00 & \\
\hline A3 & 0,91 & 0,72 & 1,00 & 0,72 & \\
\hline A4 & 1,04 & 1,00 & 1,38 & 1,00 & \\
\hline TOTAL & 4,02 & 3,65 & 4,86 & 3,68 & \\
\hline \multicolumn{5}{|c|}{$\mathrm{CR}=0,0002$} & \\
\hline
\end{tabular}


The assurance criteria of the hospital were compared from the point of view of the patients, physicians and managers and the results are shown in Table 8. Accordingly, while the most important one of the assurance criteria from the point of view of the patients is politeness of the employees (A3), the most important criteria from the point of view of the physicians is giving confidence to the patients by the employees of the hospital (A1). The most important ones from the point of view of the managers are the employees having sufficient knowledge (A4) and patients feeling safe while getting services from the hospital (A2).

Table 9: Comparison of Empathy Criteria

\begin{tabular}{|c|c|c|c|c|c|c|}
\hline \multicolumn{7}{|l|}{ Hastalar } \\
\hline Criteria & E1 & E2 & E3 & E4 & E5 & \multirow{2}{*}{$\begin{array}{l}\text { PRIORITY VECTOR } \\
0,20\end{array}$} \\
\hline E1 & 1,00 & 1,04 & 0,90 & 1,08 & 1,04 & \\
\hline E2 & 0,96 & 1,00 & 1,04 & 1,13 & 1,07 & \multirow{6}{*}{$\begin{array}{l}0,21 \\
0,19 \\
0,18 \\
0,19\end{array}$} \\
\hline $\mathbf{E 3}$ & 1,11 & 0,71 & 1,00 & 1,09 & 1,03 & \\
\hline E4 & 0,92 & 0,88 & 0,91 & 1,00 & 0,94 & \\
\hline E5 & 0,96 & 0,93 & 0,97 & 1,06 & 1,00 & \\
\hline TOPLAM & 4,95 & 4,56 & 4,82 & 5,36 & 5,08 & \\
\hline \multicolumn{6}{|l|}{$\mathrm{CR}=-0,012$} & \\
\hline \multicolumn{6}{|l|}{ Hekimler } & \multirow{8}{*}{$\begin{array}{l}\text { PRIORITY VECTOR } \\
0,24 \\
0,22 \\
0,19 \\
0,16 \\
0,17\end{array}$} \\
\hline E1 & 1,00 & 1,17 & 1,27 & 1,43 & 1,21 & \\
\hline E2 & 0,85 & 1,00 & 1,23 & 1,35 & 1,32 & \\
\hline $\mathbf{E 3}$ & 0,78 & 0,81 & 1,00 & 1,13 & 1,17 & \\
\hline E4 & 0,70 & 0,74 & 0,85 & 1,00 & 0,98 & \\
\hline E5 & 0,82 & 0,75 & 0,85 & 1,02 & 1,00 & \\
\hline TOTAL & 4,15 & 4,47 & 5,2 & 5,93 & 5,68 & \\
\hline \multicolumn{6}{|c|}{$\mathrm{CR}=-0,0002$} & \\
\hline \multicolumn{6}{|c|}{ Managers } & \multirow{8}{*}{$\begin{array}{l}\text { PRIORITY VECTOR } \\
0,207 \\
0,200 \\
0,174 \\
0,200 \\
0,217\end{array}$} \\
\hline E1 & 1,00 & 1,19 & 1,24 & 1,10 & 0,79 & \\
\hline E2 & 0,84 & 1,00 & 1,22 & 1,20 & 0,88 & \\
\hline E3 & 0,81 & 0,82 & 1,00 & 1,02 & 0,81 & \\
\hline E4 & 0,91 & 1,13 & 0,98 & 1,00 & 1,07 & \\
\hline E5 & 1,26 & 1,13 & 1,23 & 0,93 & 1,00 & \\
\hline TOTAL & 4,82 & 5,27 & 5,67 & 5,25 & 4,55 & \\
\hline \multicolumn{6}{|l|}{$\mathrm{CR}=0,019$} & \\
\hline
\end{tabular}

The empathy criteria of the hospital were compared from the point of view of the patients, physicians and managers and the results are shown in Table 9. Accordingly, while the most important one of the empathy criteria from the point of view of the patients is the employees taking care of the patients individually (E2), the most important criteria from the point of view of the physicians is the managers taking care of the patients individually (E1). The most important one of the empathy criteria from the point of view of the managers is provision of the services to all patients by the hospital at suitable times (E5).

\section{CONCLUSION}

While the most important dimension among the service quality dimensions from the point of view of the physicians is tangibles and it is followed by empathy, assurance and reliability and finally responsiveness respectively. the most important dimension among the service quality dimensions from the point of view of the patients is reliability and it is followed by responsiveness, assurance and tangibles and empathy respectively. the most important dimension among the service quality dimensions from the point of view of the managers is empathy and it is followed by reliability, tangibles, assurance and responsiveness respectively. here, it is seen that the most important service quality dimension varies for the patients, physicians and managers. in the study performed by Singh et al., (2018) in a health care institution in India and having a sample that is similar to the one of this study, it was determined that the most 
important dimension is reliability for the physicians, and it is empathy for the patients and assurance for the employees.

While the most important tangible criterion from the point of view of the patients is the wellgroomed and natty employees, it is visually attractive physical environment from the point of view of the physicians and managers. While the most important reliability criterion from the point of view of the patients and managers is keeping of the records correctly by the hospital, it is solution of the problems of the patients by the hospital, when patients encounter problems from the point of view of the physicians. The most important responsiveness criterion from the point of view of the patients, physicians and managers is informing of the patients by the hospital about the time of the service to be provided.

While the most important assurance criterion from the point of view of the patients is politeness of the employees, it is giving confidence to the patients by the employees of the hospital from the point of view of the physicians and it is the patients feeling safe while getting services from the hospital and the employees having sufficient knowledge from the point of view of the managers.

While the most important empathy criterion for the patients is the employees taking care of the patients individually, it is the managers taking care of the patients individually from the point of view of the physicians and provision of the services to all patients by the hospital at suitable times from the point of view of the managers.

Quality plays a critical role in the success of health care institutions, like all organizations. This study emphasized the importance of considering the evaluations of the patients, physicians and managers related to the service quality before designing the service delivery process of the hospital. It was determined by the study that there is an unconformity between the parties providing service and getting service regarding the service quality perceptions of them. In this respect, it is highly important to determine the expectations of patients, physicians and managers accurately and to plan the quality standards in a way to match with expectations.

The limitation of this study is performance of it in a single public hospital. This study contributes to the literature in this field since it approached the hospital service quality in our country not only from the perspective of patients, but also from the perspectives of physicians and managers and revealed that the criteria emphasized by the stakeholders varies. It may be suggested to the researchers for future studies to compare the importance levels of the different patient groups and the stakeholders of service delivery in private and public hospitals.

\section{REFERENCES}

1. Al-Borie, H.M. Damanhouri, A.M.S. (2013). Patients' Satisfaction Of Service Quality in Saudi Hospitals: A SERVQUAL Analysis, International Journal of Health Care Quality Assurance, 26(1): 20-30.

2. Biçer, F.D, Gülmez, A. (2016). Toplam Kalite Yönetimi Çerçevesinde Hizmet Pazarlaması Ve Havayolu Firmalarında Bir Araştırma. Cumhuriyet Üniversitesi Edebiyat Fakültesi Sosyal Bilimler Dergisi, 40 (1), 325-35.

3. Bolton, R. N., Drew J. H. (1991). A Longitudinal Analysis of the Impact of Service Changes on Customer Attitudes, Journal of Marketing, 55 (January), pp.1-9.

4. Chaniotakis I. E., Lymperopoulos, C. (2009). Service quality effect on satisfaction and Word of mouth in the health care industry. Managing Service Quality: An International Journal, 19(2):229-242, https://doi.org/10.1108/09604520910943206

5. Çağliyan, V. (2017). Sağlık Kurumlarında Hizmet Kalitesi Analizi: Tip Fakültesi Hastanesi Örneği, Selçuk Üniversitesi Sosyal Bilimler Enstitüsü Dergisi, (37): 254-264.

6. Demirer, Ö. and Bülbül, H. (2014). Kamu Ve Özel Hastanelerde Hizmet Kalitesi, Hasta Tatmini Ve Tercihi Arasındaki Ilişki: Karşılaştırmalı Bir Analiz. Amme Idaresi Dergisi, 47(2):95-119.

7. Devebakan, N. (2006). Sağlık Işletmelerinde Teknik Ve Algilanan Kalite. Dokuz Eylül Üniversitesi Sosyal Bilimler Enstitüsü Dergisi. 8(1):120-149.

8. Dursun, P. and Çerçi, U . (2004). Algılanan Sağlık Hizmeti Kalitesi, Algılanan Değer, Hasta Tatmini ve Davranışsal Niyet İlişkileri Üzerine Bir Araştırma. Erciyes Üniversitesi İktisadi ve İdari Bilimler Fakültesi Dergisi, 16.

9. Gülmez, M. and Kitapc1, O. (2008). Hastane Hizmet Kalitesi ve Bir Uygulama, H.U. İktisadi ve İdari Bilimler Fakültesi Dergisi, 26(1), 165-186

10. Hu H.Y., Lee Y.C. and Yen T.M. (2010). Service Quality Gaps Analysis Based On Fuzzy Linguistic SERVQUAL With A Case 
Study in Hospital Out-Patient Services, The TQM Journal, 22(5): 499-515.

11. Nadi, A., Shojaee, J., Abedi, G., Siamian, H., Abedini, E., Rostami ,F. (2016). Patients' expectations and perceptions of service quality in the selected hospitals. Med Arch.70:135-9.

12. Nekoei-Moghadam, M. and Amiresmaili, M. (2011). Hospital services quality assessment: hospitals of Kerman University of Medical Sciences, as a tangible example of a developing country. International Journal of Health Care Quality Assurance, 24: 57-66.

13. Papatya, G., Papatya, N., Hamşığlu, A. B. (2012). Sağlik İşletmelerinde Algılanan Hizmet Kalitesi ve Hasta Memnuniyeti: İki Özel Hastanede Karşılaştırmalı Bir Araştırma. Kirlkkale Üniversitesi Sosyal Bilimler Dergisi, 2 (1): 87-108.

14. Parasuraman, A., Berry, L. L., \& Zeithaml, V. A. (1991). Refinement and Reassessment Of The Servqual Scale. Journal of Retailing, 67(4), 420.

15. Parasuraman, A., Zeithaml, V. A., \& Berry, L. L. (1985). A Conceptual Model Of Service Quality And Its Implications For Future Research. The Journal Of Marketing, 41-50.

16. Parasuraman, A., Zeithaml, V. A., \& Berry, L. L. (1988). Servqual: A Multiple-Item Scale For Measuring Consumer Perc. Journal of Retailing, 64(1), 12-40.

17. Pekkaya, M, .Pulat İmamoğlu, Ö., Koca, H. (2017). Evaluation of healthcare service quality via Servqual scale: an application on a hospital. Int J Healthc Manag. 12:4, 340-347. DOI:10.1080/20479700.2017.1389474

18. Rahman, S., Erdem, R., \& Devebakan, N. (2007). Hizmet kalitesinin SERVQUAL ölçeği ile değerlendirilmesi: Elazığ'daki hastaneler üzerinde bir çalışma. Dokuz Eylül Üniversitesi Sosyal Bilimler Enstitüsü Dergisi, 9(3), 37-55.

19. Rashid Wan Edura Wan, Jusoff $\mathrm{Hj}$. Kamaruzaman. (2009). Service quality in health care setting. International Journal of Health Care Quality Assurance, 22(5), pp.471-482, https:// doi.org/10.1108/09526860910975580

20. Rezaei, S., Mati, B. K., Moradi, K., Bijan, B., Fallahi, M., \& Shokati, B,, et al. (2016).
Measurement of Quality of Educational Hospital Services by the SERVQUAL Model: The Iranian Patients' Perspective. Electronic Physician, 8(3):2101-2106. pmid:27123218

21. Qolipour, M. and Torabipour, A. (2018). Assessing medical tourism services quality using SERVQUAL model: A patient's perspective. Iran J Public Health, 47(1):10310.

22. Shafiq, M., Naeem, M.A., Munawar, Z. ve Fatima, I. (2017). Service quality assessment of hospitals in Asian context: an empirical evidence from Pakistan, Inquiry: Journal of Healthcare Organization, Provision and Financing, Vol. 54, pp. 1-12.

23. Savaş, H. and Kesmez, A.G. (2014). Hizmet Kalitesinin Servqual Modeli İle Ölçülmesi: Aile Sağlı̆̆ Merkezleri Üzerine Bir Araştırma. Pamukkale Üniversitesi Sosyal Bilimler Enstitüsü Dergisi, 17:1-13.

24. Seth N., Deshmukh S.G., Vrat P. (2005). Service quality models: a review, International Journal of Quality \& Reliability Management, 22(9), pp.913-949, https://doi.org/10.1108/02656710510625211

25. Singh, A., Prasher, A. ve Kaur, N. (2018). Assessment of hospital service quality parameters from patient, doctor and employees' perspectives, Total Quality Management \& Business Excellence, DOI: 10.1080/14783363.2018.1487283

26. Önder, G. ve Önder, E. (2015). "Analitik Hiyerarşi Süreci”" (Ed. Bahadır Fatih Yıldırım, \& Emrah Önder içinde, Çok Kriterli Karar Verme Yöntemleri. Dora Basım Yayım Dağıtım, Bursa.

27. Özgün Ova, P., Biçer, E.B., Yurcu, G. (2019). Yaşlilarda termal sağlık turizmi hizmet algısı: Sivas ili örneği, Gümüşhane Üniversitesi Sosyal Bilimler Enstitüsü Elektronik Dergisi, 10(1), 140-153.

28. Tripathi, S. N. and Siddiqui M. H. (2018). Assessing the quality of healthcare services: A SERVQUAL approach, International Journal of Healthcare Management, 1-12.

29. Zaim, H. and Tarım, M. (2010). Hasta memnuniyeti: kamu hastaneleri üzerine bir alan araştırması. Sosyal Siyaset Konferanslart Dergisi, 59(2):1-24. 